\title{
Modulation of stress response and productive performance of Litopenaeus vannamei through diet
}

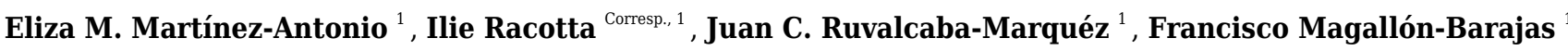 \\ 1 Programa de Acuicultura, Centro de Investigaciones Biológicas del Noroeste S. C., La Paz, B.C.S., Mexico \\ Corresponding Author: Ilie Racotta \\ Email address: iracotta@cibnor.mx
}

The high tolerance of $L$. vannamei to a wide range of salinity (1-50 psu) makes this species an excellent candidate for culture under low salinity, decreasing shrimp epidemics and water pollution in some coastal areas. However, salinity levels outside the optimal range could impose several physiological constraints that would in turn affect growth and survival, particularly in the presence of additional stressors (e.g. high densities, handling practices, and hypoxia). Despite shrimp susceptibility to individual stressors has beenwidely addressed, information regarding response to chronic and acute stressors combined and its relation to diet is scarce. Thus, the aim of our study was to determine the effect of diet on the susceptibility to chronic (low salinity) and acute (hypoxia and escape response) stressors in terms of culture performance and physiological indicators. We evaluated overall performance during culture of $L$. vannamei at lowsalinity ( $6 \mathrm{psu}$ ), fed with an experimental diet with low protein and high carbohydrate content ( $26 \%$ protein and $6 \%$ fish meal plus probiotic mixture) and compared to a commercial formula with high protein and low carbohydrate content (40\% crude protein and $20 \%$ fish meal without probiotic mixture). At the end of the rearing experiment, shrimp were exposed to two types of acute stress, hypoxia and escape. Biochemical (hemocyanin, total proteins, glucose, and lactate) and bioenergetic (adenylic energy charge and arginine phosphate levels) variables were measured to assess chronic stress response (salinity) and acute stress response (hypoxia or escape). The experimental diet resulted in higher muscle energy status that was not affected by low salinity, although lipid levels were lower under this condition. This diet partially counteracted the low performance at low salinity and promoted greater protein efficiency. Hypoxia inducedstrong hyperglycemic and lactate increase as response; whereas escape response was characterized by a depletion of arginine phosphate levels, with a stronger decrease in shrimp fed experimental diet, due to the high initial level of this reserve. Some data (glucose levels in hemolymph and lipids in hepatopancreas)suggest that shrimp under chronic stress conditions (low salinity and high densities) present a low ability to respond to subsequent acute stressors such as Peer] reviewing PDF | (2018:10:31695:1:0:NEW 18 Mar 2019) 
hypoxia or escape. This work indicates that diet canincrease the energy status of shrimp, enabling them to overcome potential multifactorial stressors, which are common in farming systems. 
1 MODULATION OF STRESS RESPONSE AND PRODUCTIVE PERFORMANCE OF

\section{Litopenaeus vannamei THROUGH DIET}

3

4 Eliza M. Martínez-Antonio, Ilie S. Racotta*, Juan C. Ruvalcaba-Marquéz, Francisco Magallón-

5 Barajas

6 Programa de Acuicultura, Centro de Investigaciones Biológicas del Noroeste S. C.

7 Calle Instituto Politécnico Nacional 195, La Paz, Baja California Sur, México

8

9 *Corresponding author: Ilie S. Racotta

10 e-mail address: $\underline{\operatorname{iracotta} @ \text { cibnor.mx }}$

11 Tel: +52612 1238400

12

13 
14 ABSTRACT. The high tolerance of $L$. vannamei to a wide range of salinity (1-50 psu) makes this species an excellent candidate for culture under low salinity, decreasing shrimp epidemics and water pollution in some coastal areas. However, salinity levels outside the optimal range could impose several physiological constraints that would in turn affect growth and survival, particularly in the presence of additional stressors (e.g. high densities, handling practices, and hypoxia). Despite shrimp susceptibility to individual stressors has been widely addressed, information regarding response to chronic and acute stressors combined and its relation to diet is scarce. Thus, the aim of our study was to determine the effect of diet on the susceptibility to chronic (low salinity) and acute (hypoxia and escape response) stressors in terms of culture performance and physiological indicators. We evaluated overall performance during culture of $L$. vannamei at low salinity (6 psu), fed with an experimental diet with low protein and high carbohydrate content (26\% protein and $6 \%$ fish meal plus probiotic mixture) and compared to a commercial formula with high protein and low carbohydrate content ( $40 \%$ crude protein and $20 \%$ fish meal without probiotic mixture). At the end of the rearing experiment, shrimp were exposed to two types of acute stress, hypoxia and escape. Biochemical (hemocyanin, total proteins, glucose, and lactate) and bioenergetic (adenylic energy charge and arginine phosphate levels) variables were measured to assess chronic stress response (salinity) and acute stress response (hypoxia or escape). The experimental diet resulted in higher muscle energy status that was not affected by low salinity, although lipid levels were lower under this condition. This diet partially counteracted the low performance at low salinity and promoted greater protein efficiency. Hypoxia induced strong hyperglycemic and lactate increase as response; whereas escape response was characterized by a depletion of arginine phosphate levels, with a stronger decrease in shrimp fed experimental diet, due to the high initial level of this reserve. Some data (glucose levels in hemolymph and lipids in hepatopancreas) suggest that shrimp under chronic stress conditions (low salinity and high densities) present a low ability to respond to subsequent acute stressors such as hypoxia or escape. This work indicates that diet can increase the energy status of shrimp, enabling them to overcome potential multifactorial stressors, which are common in farming systems.

INTRODUCTION. Shrimp culture has been one of the major growth areas in worldwide aquaculture during the last 55 years, a production of 4.156 million tons was reached in 2016 
45 (FAO, 2018). The extent of this industry is mainly on the basis of formulated feeds, which are manufactured with high contents of protein and fish meal to promote rapid shrimp growth (Shiau, 1998; Cuzon et al., 2004) with a poor consideration of environmental impact, production costs (increasing prices of fish meal and oil), and shrimp responses to several stressors inherent to the current culture systems (Tacon and Metian, 2008). Thus, there is a great need to formulate functional feeds that, in addition to providing good culture yield, enhance the capacity of shrimp to minimize stress.

The high tolerance of L. vannamei to a wide range of salinity (1-50 psu), (Pante, 1990) makes this species an excellent candidate for culture under low salinity in inland farming, developed with the aim of decreasing shrimp epidemics and water pollution in some coastal areas (Li et al., 2017). However, salinity levels outside the optimal range and prolonged exposure could impose several physiological constraints that would in turn affect growth and survival. This is particularly the case for culture under low salinities, where hyper-osmoregulation implies high energy demand and therefore, nutritional requirements of shrimp grown at low salinities has been extensively studied (for reviews see Romano and Zheng, 2012; Li et al., 2017). Although, proteins plays an important role as energy source for osmoregulation, the benefits as enhancers of growth and survival at low salinity are controversial (Li et al., 2017). In contrast, a sparing effect of protein could be suggested when intermediate levels of carbohydrates are included in shrimp diet at low salinity (Wang et al., 2104; 2015). Finallty, essential lipids such as phospholipids and cholesterol, as well as supplementation of minerals resulted in better performance of shrimp at low salinity (Gong et al., 2004). In addition, supplementation of commercial probiotics increased survival but not growth in shrimp cultured at 2 psu salinity (Li et al., 2009). Supplementation of Lactobacillus plantarum improved resistance to low salinity stress test (Zheng et al., 2017).

In intensified systems, hypoxia and shrimp handling increase given the high densities. These increased factors are considered stressors since these affect shrimp physiology, causing a reduction of culture yield in terms of growth and survival. The response to stress consists in the mobilization of energy substrates (amino acids, glucose, triglycerides, among others) to produce enough energy to meet such factors (Lucas, 1996).

There are a number of researches regarding shrimp response to prolonged exposure (chronic stress) to low salinity (Rosas et al., 2001a; Li et al., 2017) and/or temporary events (acute stress) 
such as hypoxia and handling (Racotta y Palacios, 1998; Racotta et al., 2002; Aparicio-Simón et al., 2010). However, there are no studies addressing the combined effect of chronic and acute stress on shrimp capacity to overcome such stressors in terms of energy regulation through diet. Thus, the aim of our study was to determine the effect of diet on the susceptibility to chronic salinity followed by acute exposure to hypoxia and escape, in terms of culture performance and energy status.

\section{MATERIALS \& METHODS. Salinity reduction and handling of organisms.}

Litopenaeus vannamei postlarvae were obtained from the private company Acuacultura Marh (La Paz, Mexico). Postlarvae were fed with commercial feed (40\% protein level) and acclimated to experimental conditions in the experimental nutrition laboratory of the Mexican research center [Centro de Investigaciones Biologicas del Noroeste (CIBNOR)] for approximately 6 weeks.

Prior to the transfer of juveniles $(2.08 \pm 0.35 \mathrm{~g})$ to the experimental units, half of the stock was acclimated to well water at low salinity ( $6 \mathrm{psu})$. For this purpose, 400 shrimp were stocked in 500-L polyethylene tanks at low depth $(0.3 \mathrm{~m})$ and bottom area of $3.1 \mathrm{~m}^{2}$. During seven days, salinity was reduced ( $5 \mathrm{psu} /$ day) until the desired salinity was reached (Ponce-Palafox et al., 1997). Shrimp $(2.97+0.55 \mathrm{~g})$ were randomly distributed in $60 \mathrm{~L}$ aquariums at a density of 67 $\operatorname{organisms} / \mathrm{m}^{2}$.

During 42 days, shrimp were cultured at low (6.2 $\pm 0.03 \mathrm{psu}$, well water) and high (37.3 $\pm 0.05 \mathrm{psu}$, sea water) salinities under laboratory conditions $\left(25.9 \pm 0.1^{\circ} \mathrm{C}\right.$, dissolved oxygen $=6.3 \pm 0.1$ $\mathrm{mgO}_{2} \cdot \mathrm{L}^{-1}$, and photoperiod $=12 \mathrm{~h}$ : $12 \mathrm{~h}$ light: dark). Water was exchanged (80-90\%) twice a week. Two diets were tested: control and experimental, as specified hereafter, using four replicates for each diet-salinity combination and with 15 shrimp for each replicate. The feeding rate was $5 \%$ of the total biomass in four daily rations for each aquarium (9:00 h, 12:00 h, 15:00 h and 17:00 h). The following zootechnical parameters were obtained:

Weight gain $(\%)(\mathrm{WG})=\left((\text { final weight }(\mathrm{g})-\text { initial weight }(\mathrm{g}))^{*} 100\right) /$ initial weight $(\mathrm{g})$; Specific growth rate $(\%)(\mathrm{SGR})=100 *($ ln final weight $(\mathrm{g})-\ln$ initial weight $(\mathrm{g}))$ /days of experiment; Survival $(\%)=($ shrimp initial number - dead shrimp number $) /$ shrimp initial number $\times 100$; Feed conversion ratio $(\mathrm{FCR})=$ feed intake $($ dry matter $)(\mathrm{g})$ /weight gain $(\mathrm{g})$; Protein efficiency ratio $(\mathrm{PER})=$ wet weight gain $(\mathrm{g}) /$ dry protein intake $(\mathrm{g})$; and 
107

108

109

110

111

112

113

114

115

116

117

118

119

120

121

122

123

124

125

126

127

128

129

130

131

132

133

134

135

136

137

Productive performance $=($ Survival $*$ SGR $) /$ FCR .

Feed and proximal composition. The control diet was prepared in accordance with a commercial formula that consisted in high inclusion of fish meal (20\%). The experimental diet was formulated with low inclusion of fish meal (6\%) and phosphorus $(1.5 \%)$, a mixture of free amino acids, vitamins, minerals, cholesterol and Butylated hydroxytoluene (BHT). This diet was adjusted to shrimp nutritional requirements, as reported in scientific research until 2015 (Table 1). In addition, a selection of yeasts and lactobacilli in liquid medium was included in the experimental diet. Once extruded and dried, the experimental diet was subjected to baths of organic acids and oil with astaxanthin, respectively. Both diets, experimental and control, were prepared with the same sources of protein, carbohydrates, and lipids. The proximate composition of control and experimental diets is shown in Table 2.

Fatty acids were analyzed for both diets according to Palacios et al. (2005). Lipids were extracted according to Folch (1957), boron trifluoride-methanol (BF3-14\% methanol, 3-3021, Sigma, St. Louis, MO, USA) was used for hydrolysis and esterification of fatty acids. The resulting methyl esters were separated by gas chromatography (G890N, Agilent Technologies, Santa Clara, CA, USA) with a DB-23 silica column ( $30 \mathrm{~m}$ x $0.25 \mathrm{~mm}$ ID x $0.25 \mathrm{~mm}$ film thickness), helium as carrier gas, a temperature ramp of $110-220^{\circ} \mathrm{C}$, and a flame ionization detector. An internal standard (23:0) was used to identify fatty acids in terms of concentration of each fatty acid corrected. Fatty acid composition of both diets is presented in Table 3 .

Stress tests and biochemical analysis. Stress tests were divided in three groups: hypoxia, escape response, and control. Ten shrimp were considered for each group and salinity-diet combination. The shrimp were fasted for 15 hours prior to the stress test. For hypoxia, dissolved oxygen was decreased by nitrogen bubbling to $1.0 \pm 0.5 \mathrm{mg} \mathrm{L}^{-1}$ for $30 \mathrm{~min}$. The escape response (tail-flipping) was induced by prodding shrimp until exhaustion (around $30 \mathrm{~s}$ ), which is characterized by a prolonged unwillingness to respond by tail-flipping (Robles-Romo et al., 2016). Shrimp of the control (baseline) group were undisturbed and maintained at normoxia (5.6 $\pm 0.4 \mathrm{mg} \mathrm{L}^{-1}$ ). Immediately (less than one min) after the end of the application of the stressor applied, 100-200 $\mu 1$ of hemolymph were collected in each shrimp from the ventral sinus at the base of the first abdominal segment, this procedure was performed using a cooled-anticoagulant 
138 solution formulated with 5\% sodium oxalate in isotonic saline (Mendoza, 1992). Samples were

139 immediately frozen in liquid nitrogen and stored at $75^{\circ} \mathrm{C}$ for further analyses. The same

140 sampling procedure was applied for control shrimp to obtain baseline values in the absence of

141 stress.

142 Hemolymph was centrifuged at $1350 \mathrm{~g}$ for $10 \mathrm{~min}$ at $4^{\circ} \mathrm{C}$, plasma was collected for

143 quantification of hemocyanin, total proteins, glucose, and lactate. The hepatopancreas and

144 muscle (first abdominal segment) were dissected, lyophilized, grinded, re-hydrated and

145 homogenized for quantification of levels of total proteins, total lipids, and triglycerides.

146 Commercial kits were employed to determine lactate (PAP, Randox, U. K.), glucose (GOD-PAP,

147 Boehringer Mannheim GmbH, Germany), and triglycerides (GPO-PAP, Randox), methods were

148 adapted to microplates (Palacios et al., 1999).

149 Plasma was 1:100 with saline isotonic solution (450 $\mathrm{mM} \mathrm{NaCl}$ and $10 \mathrm{mMKCl})$. Total proteins

150 were determined according to Bradford (1976) using a commercial reagent concentrate (Bio-

151 Rad, 500-0006) and bovine serum albumin (Sigma, A-3912) as standard. Total proteins were

152 read on a microplate reader at $595 \mathrm{~nm}$ (Multiscan GO, Thermo Fisher Scientific, Waltham, MA).

153 In hepatopancreas and muscle homogenates, total protein was determined after digestion with

$154 \mathrm{NaOH}(0.1 \mathrm{~N})$ at dilution of 1:20.

155 Hemocyanin was measured directly from 10- $\mu$ l plasma diluted 1:20 with saline isotonic solution.

156 Absorbance was read at $335 \mathrm{~nm}$ and concentrations were calculated using an extinction

157 coefficient $\left(\mathrm{E}^{1 \%}\right)$ of 2.83 for shrimp hemocyanin (Hagerman, 1986). Total lipids were determined

158 by the sulphophosphovanillin method (Barnes and Blackstock, 1973).

159 Abdominal muscle was dissected and homogenized under cryogenic conditions. Extraction and

160 analysis of adenylic nucleotides and arginine phosphate were performed according to Robles-

161 Romo et al. (2016). Extraction consisted on homogenization in 10\% trichloroacetic acid and

162 neutralization by means of a mixture of trioctylamine and dichloromethane $(1: 5 \mathrm{v} / \mathrm{v})$.

163 Nucleotides were separated by ion pairing reverse phase high-performance liquid

164 chromatography (HPLC) (model 1100, Agilent Technologies, Santa Clara, CA, USA) with an

165 octadecylsilane C18 column (Hyper Clone $150 \mathrm{~mm}$ length, $4.6 \mathrm{~mm}$ internal diameter, $3 \mu \mathrm{m}$

166 particle size diameter, Phenomenex, Torrance, CA, USA) and a security guard cartridge C18 (40

$167 \mathrm{~mm}$ length, $3.0 \mathrm{~mm}$ internal diameter, Phenomenex). Conditions of this procedure were the

168 following: a flow rate of $0.8 \mathrm{~mL} \mathrm{~min}^{-1}$ using a mobile phase of $0.15 \mathrm{M} \mathrm{NaH}_{2} \mathrm{PO}_{4}$ buffer, $3 \mathrm{mM}$ 
169 of tetrabutylammonium as the ion-pairing agent, and $8 \%$ methanol adjusted to $\mathrm{pH} 6.0$ with $5 \mathrm{~N}$

$170 \mathrm{NaOH}$. The adenylic energy charge (AEC) was calculated in accordance with Atkinson (1968):

Statistical analysis. Homoscedasticity of variances and normality of data were verified. A Twofactor analysis of variance (ANOVA) (2x2) was employed to determine the effect of salinity (6 and $37 \mathrm{psu}$ ) and diet (control and experimental) over the zootechnical parameters in terms of weight gain, SGR, PER, FCR, survival, and productive performance. A trifactorial ANOVA $(2 \mathrm{x}$ $2 \times 3$ ) was performed to determine the influence of salinity (6 and $37 \mathrm{psu}$ ), diet (control and experimental) and stress factor (hypoxia, escape response, and baseline) over metabolic variables in hemolymph, muscle, and hepatopancreas. Only, when a significant triple interaction was observed, individual means for each salinity-diet or salinity-diet-stress combination were compared (Tukey HSD test) and differences are indicated in tables. Otherwise, global means within each factor or two-factor combination are mentioned and compared in text, together with the corresponding significant main effect of this factor or the two-factor interaction. The software used was STATISTICA (version 10.0). Differences were considered significant al $P<0.05$. Means with different letters are statistically different.

186

187

188

189

190

191

192

193

194

RESULTS. Productive performance. Shrimp growth in terms of $\mathrm{WG}\left(\mathrm{F}_{1,12}=35.8, \mathrm{P}=\right.$ $0.00006)$ and SGR $\left(F_{1,12}=15.1, P=0.0022\right)$, was significantly affected by the interaction between salinity and diet, shrimp fed control diet and reared at 6 psu presented significantly lower values when compared to those reared at $37 \mathrm{psu}$ and fed the same diet. Similarly, the lowest PER $\left(\mathrm{F}_{1,12}=6.4, \mathrm{P}=0.026\right)$ and highest $\mathrm{FCR}\left(\mathrm{F}_{1,12}=6.2, \mathrm{P}=0.029\right)$ were detected in shrimp fed control diet and reared at $6 \mathrm{psu}$, therefore, these presented the lowest productive performance when compared with the rest of the treatments (Table 4).

In addition, as shown in table 4, survival was higher in shrimp fed experimental diet than those fed control diet (main effect of diet $\mathrm{F}_{1,12}=8.0, \mathrm{P}=0.015$ ). However, such effect is due to the significantly lower survival of shrimp reared at $6 \mathrm{psu}$ and fed control diet $(72.2 \pm 6.5 \%)$ (interaction, $\mathrm{F}_{1,12}=5.9, \mathrm{P}=0.031$ ). 
199 Biochemical responses. Shrimp grown at low salinity (6 psu) presented significantly lower 200 levels glucose $\left(16.9 \pm 1.4 \mathrm{mg} . \mathrm{dL}^{-1}\right)$ when compared to shrimp at high (37 psu) salinity $(25.7 \pm 2.5$ $201 \mathrm{mg} \cdot \mathrm{dL}^{-1}$, main effect $\mathrm{F}_{1,97}=21.7, \mathrm{P}=0.00001$ ). Hemocyanin was also affected by salinity (main 202 effect $\mathrm{F}_{1,99}=5.3, \mathrm{P}=0.023$ ); however, such effect was dependent on diet (interaction $\mathrm{F}_{2,99}=5.0$, $203 \mathrm{P}=0.0084)$ : differences between both salinities were observed only for the experimental diet (6 204 psu: $51.5 \pm 3.8 \mathrm{mg} \cdot \mathrm{mL}^{-1}$ and 37 psu: $\left.69.1 \pm 4.1 \mathrm{mg} \cdot \mathrm{mL}^{-1}, \mathrm{P}<0.01\right)$. Diet as single factor did not 205 206 affect any variable in hemolymph, although several interactions were observed between diet and salinity or stress, as described furtherly.

Stress affected significantly all of the variables in hemolymph, both as single factor or combined with salinity and diet (Table 5). Particular effects of hypoxia and escape response were observed for the different variables analyzed. Protein levels were significantly lower after escape response (84.1 $\left.\pm 4.3 \mathrm{mg} . \mathrm{mL}^{-1}\right)$ when compared to baseline and hypoxia $\left(114.9 \pm 7.1\right.$ and $106.4 \pm 6.9 \mathrm{mg} \cdot \mathrm{mL}^{-1}$, respectively, stress main effect $\left.F_{2,97}=6.9, P=0.0016\right)$. Hemocyanin was not affected by stress as single factor, although all interactions were significant (Salinity x stress, $\mathrm{F}_{2,99}=4.3, \mathrm{P}=0.016$, Diet $x$ stress, $F_{1,99}=6.1, P=0.0031$ and Salinity $x$ Diet $x$ stress, $\left.F_{2,99}=5.0, P=0.0084\right)$. For example, hemocyanin levels increased after escape response in shrimp grown at 6 psu and fed control diet, whereas a decrease (although not significant) was observed in those fed experimental diet at the same salinity, and no effect was observed at 37 psu for both diets (Table (35.8 $\left.\pm 3.1 \mathrm{mg} . \mathrm{mL}^{-1}\right)$ when compared to undisturbed or induced to escape shrimp $(14.3 \pm 1.3$ and $14.2 \pm 1.1 \mathrm{mg} \mathrm{dL}^{-1}$, respectively, stress main effect $\mathrm{F}_{2,97}=51.2, \mathrm{P}<0.00001$ ). Moreover, as denoted by the significant interaction, the influence of hypoxia was more pronounced at $37 \mathrm{psu}$ than at $6 \mathrm{psu}\left(44.8 \pm 4.9 \mathrm{vs} 26.7 \pm 2.2 \mathrm{mg} \mathrm{dL}^{-1}\right.$, respectively, Salinity x stress $\mathrm{F}_{2,97}=5.4, \mathrm{P}=$ $0.0061)$ and in shrimp fed experimental diet with regard to those fed control diet $(40.4 \pm 2.4 \mathrm{vs}$ $30.6 \pm 2.9 \mathrm{mg} \mathrm{dl}^{-1}$, respectively, Diet x stress $\left.\mathrm{F}_{2,97}=5.5, \mathrm{P}=0.0056\right)$. Lactate significantly increased in response to both stress conditions, although it was more pronounced at hypoxia $\left(57.3 \pm 4.0 \mathrm{mg} \mathrm{dL}^{-1}\right)$ than at escape response $\left(18.3 \pm 1.0 \mathrm{mg} \mathrm{dL}^{-1}\right)$, when compared to baseline values $\left(8.0 \pm 0.4 \mathrm{mg} \mathrm{dL}^{-1}\right.$, stress main effect $\left.\mathrm{F}_{2,99}=116.9, \mathrm{P}<0.00001\right)$. Lipid and triglyceride (TG) levels in hepatopancreas were significantly lower at 6 psu (164.5 \pm 12.3 and $43.9 \pm 3.4 \mathrm{mg} . \mathrm{g}^{-1}$, respectively) than at $37 \mathrm{psu}\left(204.5 \pm 7.8\right.$ and $57.9 \pm 1.8 \mathrm{mg} \cdot \mathrm{g}^{-1}$ salinity main effect $\mathrm{F}_{1,103}=7.9, \mathrm{P}=0.0059$ and $\mathrm{F}_{1,103}=18.4, \mathrm{P}=0.00004$, respectively). 
230 However, as reflected in the significant interaction, such effect was strongly dependent on diet,

231 since it was detected for the control but not for the experimental diet (interaction $\mathrm{F}_{1,103}=9.0, \mathrm{P}=$ 2320.0034 and $F_{1,103}=11.3, P=0.0011$, respectively). In addition, for lipids, the significantly lower 233 values at low salinity with regard to high salinity were observed in shrimp submitted to hypoxia 234 and escape stresses, as detected in the significant triple interaction (Table 6, $\mathrm{F}_{2,103}=3.1, \mathrm{P}=$ 235 0.049). For triglycerides, the influence of diet as single factor was significant, the highest levels 236 were found in shrimp fed experimental diet $\left(59.0 \pm 2.3\right.$ vs $42.8 \pm 3.0 \mathrm{mg} \cdot \mathrm{g}^{-1}, \mathrm{~F}_{1,103}=24.4, \mathrm{P}=$ 237 0.000003). Protein levels in hepatopancreas were affected by salinity, however, this effect 238 depended on diet and stress condition, as indicated by the significant interactions $\left(\mathrm{F}_{1,103}=6.6, \mathrm{P}\right.$ $239=0.011$ and $\mathrm{F}_{2,103}=10.1, \mathrm{P}=0.0001$, respectively). Protein levels were higher in shrimp fed 240 control diet at $6 \mathrm{psu}\left(329.9 \pm 20.8 \mathrm{mg} \mathrm{g}^{-1}\right)$ than those fed experimental diet at the same salinity $241\left(266.2 \pm 15.9 \mathrm{mg} \cdot \mathrm{g}^{-1}\right)$, whereas similar levels for both diets were observed at $37 \mathrm{psu}$. A significant 242 interaction was detected between salinity and stress given that protein levels increased with 243 hypoxia in shrimp grown at $37 \mathrm{psu}$ (344 vs $\pm 24.9 \mathrm{mg} \mathrm{g}^{-1} \mathrm{vs}$ baseline values of $276.5 \pm 13.9 \mathrm{mg}$.

$244 \mathrm{~g}^{-1}$ ), whereas a reverse trend (although not significant) was observed at 6 psu (Baseline: $304 \pm$ $24528.4 \mathrm{mg} \mathrm{g}^{-1}$; hypoxia $\left.251.6 \pm 15.8 \mathrm{mg} \mathrm{g}^{-1}\right)$.

246 Lactate levels in muscle were significantly lower at $6 \mathrm{psu}\left(5.5 \pm 0.3 \mathrm{mg} \cdot \mathrm{g}^{-1}\right)$ than at $37 \mathrm{psu}$

$247\left(7.2 \pm 0.2 \mathrm{mg} \cdot \mathrm{g}^{-1}, \mathrm{~F}_{1,102}=30.3, \mathrm{P}<0.00001\right)$, and affected by stress with a significant increase in 248 the escape response $\left(7.6 \pm 0.3 \mathrm{mg} . \mathrm{g}^{-1}\right.$ vs baseline values $5.5 \pm 0.3 \mathrm{mg} . \mathrm{g}^{-1}$ and $6.0 \pm 0.3 \mathrm{mg} . \mathrm{g}^{-1}$ in 249 shrimp exposed to hypoxia, $\left.\mathrm{F}_{2,102}=16.7, \mathrm{P}<0.00001\right)$. As shown by significant interaction 250 salinity $\mathrm{x}$ diet, $\left(\mathrm{F}_{1,102}=4.2, \mathrm{P}=0.043\right)$, shrimp fed experimental diet presented significantly higher 251 levels of lactate in the muscle $\left(6.4 \pm 0.4 \mathrm{mg}\right.$. $\left.\mathrm{g}^{-1}\right)$ with regard to those fed control diet $(4.5 \pm 0.4$ $\left.252 \mathrm{mg} \cdot \mathrm{g}^{-1}\right)$, only at 6 psu. Protein levels in muscle significantly increased with both stressors 253 (hypoxia $=625.5 \pm 11.5 \mathrm{mg} \cdot \mathrm{g}^{-1}$ and escape response $=705.0 \pm 20.4 \mathrm{mg} \cdot \mathrm{g}^{-1}$ ) when compared to 254 baseline levels $\left(550.3 \pm 19.3 \mathrm{mg} \cdot \mathrm{g}^{-1}\right.$, stress main effect $\left.\mathrm{F}_{2,102}=18.9, \mathrm{P}<0.00001\right)$. In contrast, 255 lipid levels in muscle significantly increased under escape stress $\left(49.0 \pm 2.5 \mathrm{mg} \cdot \mathrm{g}^{-1}\right)$ when 256 compared to hypoxia and baseline values $\left(36.8 \pm 2.1\right.$ and $33.1 \pm 2.4 \mathrm{mg} \cdot \mathrm{g}^{-1}, \mathrm{~F}_{2,102}=14.3, \mathrm{P}<$ 257 0.00001). Experimental diet significantly increased the total lipids in muscle (42.9 $\left.\pm 2.2 \mathrm{mg} \cdot \mathrm{g}^{-1},\right)$ 258 in comparison with control diet $\left(36.3 \pm 1.9 \mathrm{mg} \cdot \mathrm{g}^{-1}\right.$, diet effect $\left.\mathrm{F}_{1,102}=7.3, \mathrm{P}=0.008041\right)$. 259 On the other hand, Arg-P was significantly higher in shrimp fed experimental diet (4.6 \pm 0.5 $260 \mu$ moles. $\left.\mathrm{g}^{-1}\right)$ than in those fed control diet $\left(1.6 \pm 0.2 \mu\right.$ moles. $\mathrm{g}^{-1}$, diet effect $\mathrm{F}_{1,100}=35.6, \mathrm{P}<$ 
261 0.00001). Conversely, a decrease of Arg-P was observed following the escape response (1.5 \pm 0.2 $262 \mu$ moles. $\left.{ }^{-1}\right)$ when compared to baseline values $\left(4.7 \pm 0.6 \mu\right.$ moles.g $\left.{ }^{-1}\right)$, whereas a slight and non263 significant decline was observed in shrimp submitted to hypoxia $\left(3.6 \pm 0.7 \mu\right.$ moles. g $^{-1}$, stress 264 effect $\left.\mathrm{F}_{2,100}=12.9, \mathrm{P}=0.00001\right)$. However, as indicated by the interaction between diet and stress $265\left(\mathrm{~F}_{2,100}=3.2, \mathrm{P}=0.044\right)$, the decline following escape response was not significant in the control 266 diet, as baseline initial levels were lower than in experimental diet. Moreover, the triple 267 interaction involved salinity $\left(\mathrm{F}_{2,100}=3.5, \mathrm{P}=0.036\right)$, and indicated that for individual mean 268 comparisons, the influence of escape response was significant in the combination of 6 psu 269 salinity and experimental diet only (Table 7). Similarly, AEC was higher with the experimental $270 \operatorname{diet}(0.82 \pm 0.01)$ than the control $(0.71 \pm 0.01)$, given the higher content of ATP $(7.1 \pm 0.2 \mathrm{vs}$ $2715.1 \pm 0.2 \mu$ moles. $\left.\mathrm{g}^{-1}\right)$, but also to lower content of ADP (2.6 $\pm 0.1 \mathrm{vs} 3.3 \pm 0.1 \mu$ moles. $\left.\mathrm{g}^{-1}\right)$ and AMP $272\left(0.47 \pm 0.05\right.$ vs $1.15 \pm 0.08 \mu$ moles. $\left.\mathrm{g}^{-1}\right)$ when compared to control diet (diet factor, $\mathrm{F}_{1,102}=61.9, \mathrm{P}$ $<0.00001, \mathrm{~F}_{1,102}=53.9, \mathrm{P}<0.00001, \mathrm{~F}_{1,102}=23.5, \mathrm{P}=0.00004, \mathrm{~F}_{1,102}=59.5, \mathrm{P}=0.00000$,

274 respectively). The total adenylic nucleotide (TAN) concentration was also higher in shrimp fed 275 experimental diet $\left(10.2 \pm 0.2 \mu\right.$ moles.g $\left.{ }^{-1}\right)$ when compared to control diet $\left(9.6 \pm 0.17 \mu\right.$ moles.g ${ }^{-1}$, 276 diet effect $\mathrm{F}_{1,102}=6.7, \mathrm{P}=0.011$ ). In addition, ADP, AMP and TAN levels were lower at $37 \mathrm{psu}$

$277\left(2.7 \pm 0.1,0.68 \pm 0.06\right.$ and $9.3 \pm 0.17 \mu$ moles. ${ }^{-1}$, respectively) than at $6 \mathrm{psu}(3.2 \pm 0.1,0.94 \pm 0.09$ and $27810.6 \pm 0.2 \mu$ moles. $g^{-1}$, salinity effect $\mathrm{F}_{1,102}=8.3, \mathrm{P}=0.0048, \mathrm{~F}_{1,102}=8.7, \mathrm{P}=0.004$ and $\mathrm{F}_{1,102}=6.7$, $279 \mathrm{P}=0.011$, respectively). However, the significant interaction found between diet and salinity 280 indicated that salinity effects was observed only for the control diet in the case of AMP and for 281 the experimental diet in the case of TAN (Table 7, interaction salinity $\mathrm{x}$ diet, $\mathrm{F}_{1,102}=4.5, \mathrm{P}=0.036$ 282 and $\mathrm{F}_{1,102}=4.1, \mathrm{P}=0.047$, respectively). Finally, AEC and levels of nucleotides did not show any 283 significant differences during acute stress (hypoxia or escape).

DISCUSSION. According to this research, is possible to increase shrimps energy status (AEC 286 and Arg-P) by means of dietary manipulation which also resulted in potential improvement of growth performance and modulation of stress response of L. vannamei to multiple stressors (low salinity, hypoxia and manipulation).

Productive performance at low salinity and diet. Despite L. vannamei is considered a 291 euryhaline shrimp with a tolerance to salinity ranging 1 to 50 psu (Pante, 1990), previous 
292 literature and our study indicate that growth performance and survival is affected at low salinity

293 due to the high energy requirements, mainly for osmoregulation (for reviews see Romano and

294 Zheng, 2012; Li et al., 2017). However, the majority of studies were carried out at salinities

295 below 5 psu, while this work considered 6 psu in order to simulate the typical salinity of well

296 water in Baja California Sur. The latter still is a suboptimal salinity given that growth and

297 survival were lower under this condition when shrimp were fed control diet. In contrast, the

298 experimental diet in spite of low protein level, improved overall performance in culture, as

299 dietary manipulation of macro and micronutrients enhances growth performance and

300 physiological adaptation of L. vannamei at low salinity, as previously reported (Gong et al.,

301 2004; Roy et al, 2006; Wang et al., 2014; Xu et al., 2017a)., and discussed below.

302 Protein is the most important dietary component; therefore, it has received special attention as

303 strategy to enhance growth and survival under the assumption that this energy source improves

304 osmoregulation effectively (Romano and Zeng, 2012). However, dietary protein requirements at

305 low salinity and their role as enhancers of growth and survival remains controversial (Li et al.,

306 2017). Survival at low salinity decreases with increasing levels of proteins in the diet (Wang et

307 al., 2005; Zhu et al. 2010; Wang et al., 2015). This statement is in accordance with our study,

308 since the lowest performance in terms of growth and survival was obtained at 6 psu with the

309 control diet (higher protein content). In contrast, several researches obtained growth

310 improvement at low salinity with higher protein content in the diet (Liu et al., 2005; Li et al.,

311 2007; Li et al., 2011), while other reports indicate that this is not always the case (Zhu et al.,

312 2010).

313 In the present work, other nutrients besides protein might have contributed to the high

314 performance observed with the experimental diet. The difference of protein content (14\%)

315 between both diets is compensated by a slightly higher lipid (1\%; Table 3$)$ content and a

316 considerably higher carbohydrate $(\mathrm{CBH})$ content (more than $10 \%$ if estimated on the basis of

317 nitrogen free extract; Table 3) in the experimental diet. In addition to performance, biochemical

318 indicators of the beneficial role of the experimental diet were also observed, since despite the

319 low content of gross energy, levels of energy-phosphorylated compounds such as Arg-P and

320 ATP in shrimp muscle were higher. Thus, this potentialized availability of cell-energy can be

321 attributed to an ostensibly better allocation of energy from lipids and CBH for osmoregulation,

322 as discussed in previous reviews on shrimp culture at low salinities (Romano and Zeng, 2012; 
323 Chen et al., 2014; Wang et al., 2016; Li et al., 2017). This explains the higher protein-efficiency

324 ratio found with the experimental diet, especially at low salinity, indicating a sparing of protein

325 for growth, while CBH and lipids are used for metabolism. In accordance, proteomic analyses

326 have revealed that glycometabolism (tricarboxylic acid cycle, glycolysis, and gluconeogenesis)

327 in the hepatopancreas is enhanced at $3 \mathrm{psu}$ (Xu et al., 2017b). Moreover, a differential use of

328 energy substrates for osmoregulation in relation to the relative levels of protein and $\mathrm{CBH}$ in diet

329 were detected for the crab, Chasmagnathus granulate, a good-eurhyaline osmoregulator (Da

330 Silva and Kucharski, 1992).

331 In a study of $\mathrm{CBH}$ in diets, improved performance (growth and survival) at low salinity was

332 detected with intermediate levels of digestible $\mathrm{CBH}(20 \%$ starch) in iso-proteinic (40\%) and iso-

333 lipidic (6\%) diets, ranging from 5 to $30 \% \mathrm{CBH}$ (Wang et al., 2014). According to estimations of

334 energy budget, when $\mathrm{CBH}$ levels increase in a diet, there is a concomitant reduction of protein

335 levels, with optimal CBH level between 26 and 30\% for maximum growth at low salinities ( 1 to

$3368 \mathrm{psu}$ ) that corresponds to an increased energy destined for growth (Wang et al., 2014). In a

337 recent study, Wang et al. (2015) used iso-energetic diets with different protein:CBH ratios of 26-

$33838 \%$ : 30-14\% and the highest growth at 3 psu was observed with a diet consisting of $19 \% \mathrm{CBH}$

339 and $34 \%$ protein. Inclusion of $\mathrm{CBH}$ in diets deserves particular consideration since shrimp are

340 supposedly not metabolically adapted to high $\mathrm{CBH}$ levels. Indeed, a limit of 33\% was suggested

341 according to the starch-digestion capacity by $\alpha$-amylase and saturation of glycogen in the

342 digestive gland (Rosas et al., 2002). Moreover, the metabolic saturation of the capacity to use

$343 \mathrm{CBH}$ is more notorious in farmed and genetically selected shrimp when compared to wild

344 populations. A reduction of allele frequency in amylase genes of domesticated shrimp (25 th

345 generation) was related to a reduced ability of shrimp to use dietary CBH (Arena et al., 2003).

346 Similarly, the $7^{\text {th }}$ generation of cultured shrimp (L. vannamei) presented high dependence of

347 protein for metabolism and immune response (Pascual et al., 2004). This explains why

348 intermediate (19-30\%) CBH levels in diets are optimal at low salinity (Wang et al., 2005; 2014;

349 2015). However, these results depend on the particular nature of each selection program with

350 regard to the development of culture over generations and specific culture conditions. Contrary

351 to the conditions employed by Arena et al., (2003) and Pascual et al. (2004), in our study, shrimp

352 were obtained from Acuacultura Mahr, this enterprise has a genetic selection program in which

353 biofloc hyper-intensive culture conditions and low protein levels in the diet are gradually 
354 implemented over successive generations. Therefore, the threshold for maximum CBH can be

355 increased through selection, and these shrimps were best adapted to high $\mathrm{CBH}$ in the diet. The

356 low growth with high level of dietary $\mathrm{CBH}$ is partially attributed to carbohydrolases-shrimp

357 deficiency, thus, it was suggested that probiotic bacteria should be included in feed to improve

358 CBH digestibility (Olmos et al., 2011). In our study, the experimental diet included a probiotic

359 mix that could have contributed to an enhanced $\mathrm{CBH}$ assimilation, given that it contained yeast,

360 bacilli and lactobacilli with CBH-processing capabilities (data not part of this research).

361 In addition, despite the difference of lipid levels between diets was low (1\%), triglyceride levels

362 in the hepatopancreas were higher in shrimp cultured at low salinity and fed experimental diet

363 (Table 6). The influence of total and specific lipid levels in diet was analyzed in relation to

364 performance at low salinity. Regarding total lipids, intermediate levels of 9\% (range: 6-12\%)

365 resulted in the highest growth at $2 \mathrm{psu}$, which can be partially attributed to a protein sparing

366 effect, as indicated by the low glutamic oxaloacetic transaminase (Xu et al., 2017a). According

367 to lipid levels and enzyme activities, Chen et al. (2014) determined that lipid metabolism

368 provides enough energy to osmoregulate efficiently at low and high salinities, improving

369 performance during culture. The level of several specific lipids such as cholesterol,

370 phospholipids and highly unsaturated fatty acids (HUFA) was also analyzed in relation to

371 performance and osmoregulatory capacities at low salinity (for reviews see Palacios and Racotta,

372 2007; Romano and Zheng, 2012; Li et al., 2017). Apparently, in our study, the beneficial effect

373 of the experimental diet at low salinity is not related with higher HUFA levels, given that the

374 opposite difference was detected: lower proportion of individual (e.g. 20:6n-3) and total HUFA.

375 The beneficial effect of the experimental diet analyzed in this research was not only related to the

376 low total protein content and high $\mathrm{CBH} /$ lipid level, but also to individual amino acids and other

377 nutrients that were included. A diet supplemented with essential amino acids in their free form is

378 a successful strategy to reduce pressure of protein demand as energy source (Claybrook 1983).

379 For example, isoleucine, leucine, threonine, and $L$-tryptophan added in their crystalline form,

380 improve performance at low salinity (Li et al., 2017). Inclusion of free amino acids can replace

381 fish meal, hence, these were included in the experimental diet, decreasing protein costs and

382 environmental deterioration, as suggested previously (Huai et al., 2009, Xie et al. 2015). With

383 regard to other nutrients, the osmoregulatory ability of shrimp improves by incorporating

384 astaxanthin (Flores et al., 2007), vitamins and minerals (Gong et al., 2004), phosphorus (Cheng 
385

386

387

388

389

390

391

392

393

394

395

396

397

398

399

400

401

402

403

404

405

406

407

408

409

410

411

412

413

414

415

et al., 2006), and microorganisms (Avnimelech, 2012) in diets. Therefore, these micronutrients were added in the experimental diet, which explains our results, although it is not possible to identify the exact nutrient or set of nutrients responsible for the improved performance at low salinity. We decided to elaborate this diet in order to evaluate the synergic effect of all the components (low protein, free amino acids, vitamins, minerals and probiotic mixture), given that individual effects are well documented, but studies considering two or more components are scarce.

Stress response. The main findings of this study must be evaluated in relation to two key concepts of stress physiology. First, energy-limiting stress tolerance, mostly applied to chronic stress during overall fitness (growth and reproduction), which is limited or suppressed due to the re-allocation of energy to cope with stress (Sokolova, 2013). As discussed earlier, this was the case for the limited growth at low salinity, although no evidence of limited energy was observed in terms of the variables measured, reserves, and cellular energy charge, including Arg-P levels. Second, increased vulnerability to a second stressor (in this study hypoxia or escape), applied in shrimp that were already exposed to a first stressful situation (low salinity in our research) (Chrousos and Gold, 1992). Hence, it was important to perform a comprehensive analysis that addressed the particular effects of acute stressors and the level of response in relation to salinity conditions, as well as the influence of diet. Under this context, the exposure to stressors entails an increase in energy demand at the cellular level, thus, shrimp fitness depends on their capacity to allocate energy, which is constrained by the physiological and nutritional state (Tseng and Hwang, 2008).

The main response to hypoxia exposure (regardless of salinity and diet) was an increase in hemolymph glucose and lactate, in accordance with the activation of anaerobic metabolism during oxygen shortage (Gäde, 1984; Abe et al., 2007; Soñanez-Organis et al., 2010). An intense muscular activity is also related to the anaerobic-metabolism activation caused by an insufficient delivery of oxygen to tissues, with its concomitant glucose and lactate increase (Yu et al, 2009; Robles-Romo et al., 2016). However, in this work, glucose did not increase right after tail flipping, as detected by Robles-Romo et al. (2016), where such response was not appreciated immediately, but only after one hour. In addition, lactate response was considerably higher with hypoxia when compared to tail flipping, this can be attributed to the duration of the stress (less 
416 than one minute for tail flipping and $30 \mathrm{~min}$ for hypoxia), also taking into account that the

417 accumulation of lactate in hemolymph was clearly associated with the duration of both stressors

418 (Gäde, 1984). In contrast, a decrease in protein levels was observed following escape, this effect

419 had not been observed in previous studies (Robles-Romo et al., 2016), however, it could be

420 related to the usage of circulating protein to satisfy muscle energy demand, as observed during

421 swimming (Duan et al., 2014).

422 Decreased AEC and Arg-P are also typical metabolic responses associated with the increase in

423 energy demands during tail flipping (Onnen and Zebe, 1983; England and Badwin, 1983; Gäde,

424 1984; Thébaullt et al., 1994; Robles-Romo et al., 2016) and oxygen shortage due to ATP

425 synthesis during hypoxia (Gäde, 1984; Abe et al., 2007; Sokolova, 2013). AEC did not present

426 significant differences in the experimental diet at 6 psu during acute stress (hypoxia or escape),

427 in fact, only mild AEC decrease was observed after $6 \mathrm{~h}$ under hypoxia (Abe et al., 2007) and $20 \mathrm{~s}$

428 of tail flipping (Robles-Romo et al., 2016).

429 Several interesting findings were observed regarding response to acute stressors in relation to

430 diet and salinity. The increase in hemolymph glucose during hypoxia was more notorious at 37

431 than at 6 psu, most probably due to the low capacity of response to a second stressor in shrimp

432 that had been submitted to a first chronic stressor (low salinity) for several weeks. Similarly,

433 protein in hepatopancreas increased during hypoxia at 37 psu only. As hemocyanin is

434 synthesized in the hepatopancreas (Senkbeil and Wriston, 1981), an increase in protein levels

435 might correspond to the synthesis of this or other proteins involved in hypoxic response (e.g.,

436 heat shock proteins) (De la Vega et al., 2006) or hypoxia-inducible factor (HIF) (Soñanez-

437 Organis et al., 2010). Such putative adaptative response was mitigated in shrimp under low

438 salinity, i.e. a previous stress condition increased vulnerability to a subsequent stressor. Other

439 result that can be related to the dual stress exposure is the significantly lower lipid level found in

440 hepatopancreas of shrimp fed control diet at 6 psu under both acute stressors (hypoxia and

441 escape response). This triple interaction indicates that with stress as single factor, lipids are not

442 mobilized to satisfy the energy demand associated with muscular activity, contrary to dual stress.

443 In turn, lipid mobilization does not occur with higher $\mathrm{CBH}$ content in the diet.

444 Regarding the interaction between stress and diet, the increase in hemolymph glucose found in

445 shrimp exposed to hypoxic stress was more pronounced when fed experimental diet, probably

446 due to the high $\mathrm{CBH}$ level in the experimental diet, as discussed earlier. Previous studies 
447 observed higher glucose levels in shrimp fed high $\mathrm{CBH}$ content, however, this was detected in

448 wild shrimp and no stressor was applied (Arena et al., 2003). As mentioned earlier, Arg-P was

449 higher in shrimp fed experimental diet and decreased to provide energy for tail flipping. In

450 shrimp fed experimental diet, this indicates a higher energy availability to cope with acute stress.

451 Therefore, the resulting levels of Arg-P after tail flipping were lower for shrimp fed control diet;

452 however, the average Arg-P consumption was higher for the experimental diet $\left(4.2 \mu \mathrm{mol} . \mathrm{g}^{-1}\right)$

453 when compared to the control $\left(1.95 \mu \mathrm{mol} . \mathrm{g}^{-1}\right)$. Moreover, the decrease was more notorious at 6

454 psu in shrimp fed control diet, which suggests that the experimental diet also copes with dual

455 stress condition.

456

457 CONCLUSIONS. According to this research, diet can increase energy status (AEC and Arg-P)

458 to overcome successfully potential multifactorial stressors, which are common in farming

459 systems. Exposure to chronic low salinity showed no evidence of limited energy in terms of

460 energy reserves at the cellular level, in contrast to acute stress by hypoxia or escape response,

461 which imposed high energy demands that depended on diet and the previous condition of chronic

462 stress of low salinity.

463

464 ACKNOWLEDGEMENTS. Authors are grateful to Sandra de la Paz for her support the experimental facilities; Ernesto Goytortúa Bores for diet preparation; and Paola Magallón Servín, Melisa López Vela, Edgar Salvador Reyes and María Cristina Galaviz who designed, formulated and provided the probiotic mixture; María Dolores Rondero Astorga for proximate analyses of diets; Roberto Hernández-Herrera and Rosalinda Salgado for technical assistance in biochemical analyses and adenylic nucleotides, respectively; and María Olivia Arjona López for fatty acids analyses. This research was funded by CONACYT (grant number 260464), CONACYT (FINNOVA) and DACI-Conacyt 296397. Authors are thankful to Mariana Díaz Santana Iturrios for editorial services in English.

\section{REFERENCES}

Abe, H., Hirai, S., and Okada, S. 2007. Metabolic responses and arginine kinase expression under hypoxic stress of the kuruma prawn Marsupenaeus japonicus. Comparative Biochemistry and Physiology-Part A: Molecular \& Integrative Physiology. 146, 40-46. https://doi.org/10.1016/j.cbpa.2006.08.027. 
504

505

506

507

508

509

510

511

512

513

Aparicio-Simón, B., Piñón, M., Racotta, R., Racotta, I.S., 2010. Neuroendocrine and metabolic responses of Pacific whiteleg shrimp Litopenaeus vannamei exposed to acute handling stress. Aquaculture 298, 308-314. https://doi.org/10.1016/j.aquaculture.2009.10.016

Arena, L., Cuzon, G., Pascual, C., Gaxiola, G., Soyez, C., Wormhoudt, A. Van, Rosas, C., 2003. Physiological and genetic variations in domestic ted and wild populations of Litopenaeus vannamei fed with different carbohydrate levels. J. Shellfish Res. 22, 269-279.

Atkinson, D.E., 1968. The Energy Charge of the Adenylate Pool as a Regulatory Parameter. Interaction with Feedback Modifiers. Biochemistry 7, 4030-4034. https://doi.org/10.1021/bi00851a033

Avnimelech, Y., 2012. Biofloc technology - A practical guide book., A practical guide book. The World Aquaculture. https://doi.org/10.13140/2.1.4575.0402

Barnes, H., Blackstock, J., 1973. Estimation of lipids in marine animals and tissues: Detailed investigation of the sulphophosphovanilun method for "total" lipids. J. Exp. Mar. Bio. Ecol. 12, 103-118. https://doi.org/10.1016/0022-0981(73)90040-3.rev

Chen, K., Li, E., Gan, L., Wang, X., Xu, C., Lin, H., Qin, J.G., and Chen, L. 2014. Growth and Lipid Metabolism of the Pacific White Shrimp Litopenaeus vannamei at Different Salinities. J. Shellfish Res. 33, 825-832. https://doi.org/10.2983/035.033.0317

Cheng, K., Hu, C., Liu, Y., Zheng, S., and Qi, X. 2006. Effects of dietary calcium, phosphorus and calcium/phosphorus ratio on the growth and tissue mineralization of Litopenaeus vannamei reared in low-salinity water. Aquaculture. 251, 472-483. https://doi.org/10.1016/j.aquaculture.2005.06.022.

Chrousos, G.P. and Gold, P.W., 1992. The Concepts of Stress and Stress System Disorders Overview of. Jama 267, 1244-52. https://doi.org/10.1001/jama.267.9.1244

Claybrook, D.L., 1983. Nitrogen Metabolism, Internal Anatomy and Physiological Regulation. https://doi.org/10.1016/B978-0-12-106405-1.50014-X

Cuzon, G., Lawrence, A., Gaxiola, G., Rosas, C., and Guillaume, J. 2004. Nutrition of Litopenaeus vannamei reared in tanks or in ponds. Aquaculture. 235, 513-551. https://doi.org/10.1016/j.aquaculture.2003.12.022.

Da Silva, Roselis S M. Kucharski, L.C.R., 1992. Effect of hyposmotic stress on the carbohydrate metabolism of crabs maintained on high protein or carbohydrate-rich diet. Comp. Biochem. Physiol. Part A Physiol. 102, 579-583. https://doi.org/10.1016/0300-9629(92)90213-A

De La Vega, E., Hall, M.R., Degnan, B.M., Wilson, K.J., 2006. Short-term hyperthermic treatment of Penaeus monodon increases expression of heat shock protein 70 (HSP70) and reduces replication of gill associated virus (GAV). Aquaculture 253, 82-90. https://doi.org/10.1016/j.aquaculture.2005.07.041 
514 Duan, Y., Zhang, X., Liu, X., and Thakur, D.N. 2014. Effect of dissolved oxygen on swimming

515

516

517

518

519

520

521

522

523

524

525

526

527

528

529

530

531

532

533

534

535

536

537

538

539

540

541

542

543

544

545

546

547

548 ability and physiological response to swimming fatigue of whiteleg shrimp (Litopenaeus vannamei). J. Ocean Univ. China. 13, 132-140. https://doi.org/10.1007/s11802-014-1974-1.

England, W. R. and Baldwin, J. 1983. Anaerobic Energy Metabolism in the Tail Musculature of the Australian Yabby Cherax destructor (Crustacea, Decapoda, Parastacidae): Role of Phosphagens and Anaerobic Glycolysis during Escape Behavior. Review. Physiol. Zool. 56, 614-622. https://doi.org/10.1086/physzool.56.4.30155884

FAO. 2018. The State of World Fisheries and Aquaculture 2018 - Meeting the sustainable development goals. Rome. Licence: CC BY-NC-SA 3.0 IGO.

Flores, M., Díaz, F., Medina, R., Re, A.D., and Licea, A. 2007. Physiological, metabolic and haematological responses in white shrimp Litopenaeus vannamei (Boone) juveniles fed diets supplemented with astaxanthin acclimated to low-salinity water. Aquac. Res. 38, 740747. https://doi.org/10.1111/j.1365-2109.2007.01720.x.

Folch, J., Lees, M., and Sloane-Stanley, G.H.,1957. A Simple Method for Quantifying Ultrasound-Triggered Microbubble Destruction. Ultrasound Med. Biol. 37, 949-957. https://doi.org/10.1016/j.ultrasmedbio.2011.03.005.

Gäde, G., 1984. Effects of oxygen deprivation during anoxia and muscular work on the energy metabolism of the crayfish, Orconectes Limosus. Comp. Biochem. Physiol. - A Mol. Integr. Physiol. 3, 495-502.

Gong, H., Jiang, D.H., Lightner, D. V., Collins, C., and Brock, D. 2004. A dietary modification approach to improve the osmoregulatory capacity of Litopenaeus vannamei cultured in the Arizona desert. Aquac. Nutr. 10, 227-236. https://doi.org/10.1111/j.13652095.2004.00294.x.

Hagerman, L., 1986. Haemocyanin concentration in the shrimp Crangon crangon (1.) after exposure to moderate hypoxia. Comp. Biochem. Physiol. Part A Physiol. 85, 721-724. https://doi.org/10.1016/0300-9629(86)90283-5

Huai, M.Y., Liu, Y.J., Tian, L.X., Deng, S.X., Xu, A.L., Gao, W., and Yang, H.J. 2009. Effect of dietary protein reduction with synthetic amino acids supplementation on growth performance, digestibility, and body composition of juvenile Pacific white shrimp, Litopenaeus vannamei. Aquac. Int. 18, 255-269. https://doi.org/10.1007/s10499-009-9241$\mathrm{y}$.

Li, E., Chen, L., Zeng, C., Chen, X., Yu, N., Lai, Q., and Qin, J.G. 2007. Growth, body composition, respiration and ambient ammonia nitrogen tolerance of the juvenile white shrimp, Litopenaeus vannamei, at different salinities. Aquaculture. 265, 385-390. https://doi.org/10.1016/j.aquaculture.2007.02.018. 
549

550

551

552

553

554

555

556

557

558

559

560

561

562

563

564

565

566

567

568

569

570

571

572

573

574

575

576

577

578

579

580

581

582

583

584

Li, E., Wang, X., Chen, K., Xu, C., Qin, J.G., and Chen, L. 2017. Physiological change and nutritional requirement of Pacific white shrimp Litopenaeus vannamei at low salinity. Rev. Aquac. 9, 57-75. https://doi.org/10.1111/raq.12104.

Li, E., Chen, L., Zeng, C., Xiong, Z., Lin, C., Sun, X., Wang Y.Q., and Hou, L.S. 2008. Effects of dietary protein levels on growth, survival, body composition and hepatopancreas histological structure of the white shrimp, Litopenaeus vannamei, at different ambient salinities. Journal of Fisheries of China. 32, 425-434.

Li, E., Arena, L., Lizama, G., Gaxiola, G., Cuzon, G., Rosas, C., and Chen, L. 2011. Glutamate dehydrogenase and $\mathrm{Na}+-\mathrm{K}+$ ATPase expression and growth response of Litopenaeus vannamei to different salinities and dietary protein levels. Chin. J. Ocean. Limnol. 29, 343349. https://doi.org/10.1007/s00343-011-0093-8

Li, P., Wang, X., Murthy, S., Gatlin III, D.M., Castille, F.L., Lawrence, A.L. 2009. Effect of dietary supplementation of brewer's yeast and GroBiotic -A on growth, immune responses, and low-salinity tolerance of pacific white shrimp Litopenaeus vannamei cultured in recirculating systems. Journal of Applied Aquaculture 21: 110-119. https://doi.org/10.1080/10454430902892917

Liu, D.H., He, J.G., Liu, Y.J., Zheng, S.X., and Tian, L.X. 2005. Effects of dietary protein levels on growth performance and immune condition of Pacific white shrimp Litopenaeus vannamei juveniles at very low salinity. Acta Scientiarum Naturalium Universitatis Sunyatseni. 44(Suppl 2), 217-223.

Lucas, A. 1996. Bioenergetics of Aquatic Animals. Taylor y Francis. 169 pp.

Mendoza, R. 1992. Etude de la vitellogénse et de sa stimulation chez les crevettes penéides par des facteurs hetérologues et homologues. Thése de Doctorat; Univerité de Bretagne Occidentale. 202 p.

Olmos, J., Ochoa, L., Paniagua-Michel, J., and Contreras, R. 2011. Functional Feed Assessmen on Litopenaeus vannamei Using 100 \% Fish Meal Replacement by Soybean Meal, High Levels of Complex Carbohydrates and Bacillus Probiotic Strains 1, 1119-1132. https://doi.org/10.3390/md9061119.

Onnen, T., Zebe, E., 1983. Energy metabolism in the tail muscle of the shrimp Crangon crangon during work and subsequent recovery. Comp. Biochem. Physiol. 74A, 833-838.

Palacios, E., Racotta, I.S., 2007. Salinity stress test and its relation to future performance and different physiological responses in shrimp postlarvae. Aquaculture 268, 123-135. https://doi.org/10.1016/j.aquaculture.2007.04.034

Palacios, E., Ramírez, J.L., Ibarra, A.M., and Racotta, I.S. 1999. Reproductive exhaustion in shrimp Penaeus vannamei reflected in larval biochemical composition, survival and growth. Aquaculture.171, 309-321. https://doi.org/10.1016/S0044-8486(98)00393-7

Peer) reviewing PDF | (2018:10:31695:1:0:NEW 18 Mar 2019) 
585

586

587

588

589

590

591

592

593

594

595

596

597

598

599

600

601

602

603

604

605

606

607

608

609

610

611

612

613

614

615

616

617

618

619

Palacios, E., Racotta, I.S., Kraffe, E., Marty, Y., Moal, J., Samain, J.F., 2005. Lipid composition of the giant lion's-paw scallop (Nodipecten subnodosus) in relation to gametogenesis: I. Fatty acids. Aquaculture 250, 270-282. https://doi.org/10.1016/j.aquaculture.2005.04.070

Pante, M.J.R. 1990. Influence of environmental stress on the heritability of molting frequency and growth rate of the penaeid shrimp, Penaeus vannamei. University of Houston-Clear lake, Houston, TX, USA, M.Sc. Thesis. 95 p.

Pascual, C., Zenteno, E., Cuzon, G., Sánchez, A., Gaxiola, G., Taboada, G., Suárez, J., Maldonado, T., Rosas, C., 2004. Litopenaeus vannamei juveniles energetic balance and immunological response to dietary protein. Aquaculture 236, 431-450. https://doi.org/10.1016/j.aquaculture.2004.01.015

Ponce-palafox, J., Martinez-palacios, C.A., and Ross, L.G. 1997. The effects of salinity and temperature on the growth and survival rates of juvenile white shrimp. Aquaculture. 157, 107-115. https://doi.org/10.1016/S0044-8486(97)00148-8

Racotta I. S.; E.Palacios, 1998. Hemolymph Metabolic in Response to Experimental Manipulation Stress and Serotonin Injection in Panaeus vannammei. J. World Aquac. 29, $1-6$.

Racotta, I.S., Palacios, E., and Méndez, L. 2002. Metabolic Responses to Short and Long-term Exposure tu Hipoxia in White Shrimo (Panaeus vannamei). Mar. Freshw. Behav. Physiol. 35, 269-275. https://doi.org/10.1080/1023624021000019333.

Robles-Romo, A., Zenteno-Savín, T., and Racotta, I.S. 2016. Bioenergetic status and oxidative stress during escape response until exhaustion in whiteleg shrimp Litopenaeus vannamei. J. Exp. Mar. Bio. Ecol. 478, 16-23. https://doi.org/10.1016/j.jembe.2016.01.016.

Romano, N. and Zeng, C. 2012. Osmoregulation in decapod crustaceans: Implications to aquaculture productivity, methods for potential improvement and interactions with elevated ammonia exposure. Aquaculture. 334-337, 12-23. https://doi.org/10.1016/j.aquaculture.2011.12.035.

Rosas, C., Cuzon, G., Gaxiola, G., Pascual, C., Taboada, G., Arena, L., and Van Wormhoudt, A. 2002. An energetic and conceptual model of the physiological role of dietary carbohydrates and salinity on Litopenaeus vannamei juveniles. J. Exp. Mar. Bio. Ecol. 268, 47-67. https://doi.org/10.1016/S0022-0981(01)00370-7.

Rosas, C., Cuzon, G., Taboada, G., Pascual, C., Gaxiola, G., and Van Wormhoudt, A. 2001 a. Effect of dietary protein and energy levels on growth, oxygen consumption, haemolymph and digestive gland carbohydrates, nitrogen excretion and osmotic pressure of Litopenaeus vannamei (Boone) and L. setiferus (Linnaeus) juveniles (Crustacea, Decapoda; Penae. Aquac. Res. 32, 531-547. https://doi.org/10.1046/j.1365-2109.2001.00573.x. 
620

621

622

623

624

625

626

627

628

629

630

631

632

633

634

635

636

637

638

639

640

641

642

643

644

645

646

647

648

649

650

651

652

653

654

655

Roy, L.A., Davis, D.A., and Saoud, I.P. 2006. Effects of lecithin and cholesterol supplementation to practical diets for Litopenaeus vannamei reared in low salinity waters. Aquaculture. 257, 446-452. https://doi.org/10.1016/j.aquaculture.2006.02.059

Senkbeil, E.G. and Wriston, J.G.Jr. 1981. Hemocyanin synthesis in the american lobster, Homarus americanus. Comp. Biochem. Physiol. 68B, 163-171.

https://doi.org/10.1016/0305-0491(81)90198-X

Shiau, S., 1998. Nutrient requirements of penaeid shrimps. Aquaculture. 164, 77-93. https://doi.org/10.1016/S0044-8486(98)00178-1

Soñanez-Organis, J.G., Racotta, I.S., and Yepiz-Plascencia, G. 2010. Silencing of the hypoxia inducible factor 1 -HIF-1- obliterates the effects of hypoxia on glucose and lactate concentrations in a tissue-specific manner in the shrimp Litopenaeus vannamei. J. Exp. Mar. Bio. Ecol. 393, 51-58. https://doi.org/10.1016/j.jembe.2010.06.031

Sokolova, I.M., 2013. Energy-limited tolerance to stress as a conceptual framework to integrate the effects of multiple stressors. Integr. Comp. Biol. 53, 597-608. https://doi.org/10.1093/icb/ict028

Tacon, A.G.J., Cody, J.J., Conquest, L.D., Divakaran, S., Forster, I.P., and Decamp, O.E. 2002. Effect of culture system on the nutrition and growth performance of Pacific white shrimp Litopenaeus vannamei (Boone) fed different diets. Aquac. Nutr. 8, 121-137. https://doi.org/10.1046/j.1365-2095.2002.00199.x

Thebault, M., Raffin, J., Pichon, R., Smine, a, 1994. 31P NMR studies of the metabolic changes in the prawns Palaemon serratus and P. elegans during exercise. Mar. Ecol. Prog. Ser. 111, 73-78. https://doi.org/10.3354/meps 111073

Tseng, Y.C. and Hwang, P.P. 2008. Some insights into energy metabolism for osmoregulation in fish. Comp. Biochem. Physiol. - C Toxicol. Pharmacol. 148, 419-429. https://doi.org/10.1016/j.cbpc.2008.04.009.

Wang, X., Li, E., Qin, J.G., Wang, S., Chen, X., Cai, Y., Chen, K., Hou, Y., Yu, N., Zhang, M., Du, Z., and Chen, L. 2014. Growth, Body Composition, and Ammonia Tolerance of Juvenile White Shrimp Litopenaeus vannamei Fed Diets Containing Different Carbohydrate Levels at Low Salinity. J. Shellfish Res. 33, 511-517. https://doi.org/10.2983/035.033.0220.

Wang, X.D., Li, E.C., Wang, S.F., Qin, J.G., Chen, X.F., Lai, Q.M., Chen, K., Xu, C., Gan, L., Yu, N., Du, Z.Y., and Chen, L.Q. 2015. Protein-sparing effect of carbohydrate in the diet of white shrimp Litopenaeus vannamei at low salinity. Aquac. Nutr. 21, 904-912. https://doi.org/10.1111/anu.12221

Wang, X., Ma, S., and Dong, S. 2005. Effects of salinity and dietary protein levels on survival, growth and energy conversion of juvenile Litopenaeus vannamei. Periodical of Ocean University of China. 35:33-37. http://europepmc.org/abstract/CBA/519331

Peer) reviewing PDF | (2018:10:31695:1:0:NEW 18 Mar 2019) 
656

657

658

659

660

661

662

663

664

665

666

667

668

669

670

671

672

673

674

675

676

677

678
Xie, S.W., Tian, L.X., Li, Y.M., Zhou, W., Zeng, S.L., Yang, H.J., and Liu, Y.J. 2015. Effect of proline supplementation on anti-oxidative capacity, immune response and stress tolerance of juvenile Pacific white shrimp, Litopenaeus vannamei. Aquaculture. 448, 105-111. https://doi.org/10.1016/j.aquaculture.2015.05.040.

Xu, C., Li, E., Liu, Y., Wang, S., Wang, X., Chen, K., Qin, J.G., and Chen, L. 2017a. Effect of dietary lipid level on growth, lipid metabolism and health status of the Pacific white shrimp Litopenaeus vannamei at two salinities. Aquac. Nutr. 24, 204-214. https://doi.org/10.1111/anu.12548.

Xu, C., Li, E., Liu, Y., Wang, X., Qin, J.G., and Chen, L. 2017b. Comparative proteome analysis of the hepatopancreas from the Pacific white shrimp Litopenaeus vannamei under long-term low salinity stress. J. Proteomics. 162, 1-10. https://doi.org/10.1016/j.jprot.2017.04.013.

Yu, X., Zhang, X., Zhang, P., Yu, C., 2009. Critical swimming speed, tail-flip speed and physiological response to exercise fatigue in kuruma shrimp, Marsupenaeus japonicus. Comp. Biochem. Physiol. - A Mol. Integr. Physiol. 153, 120-124. https://doi.org/10.1016/j.cbpa.2009.01.012

Zheng, X., Duan, Y., Dong, H., Zhang, J. 2017. Effects of dietary Lactobacillus plantarum in different treatments on growth performance and immune gene expression of white shrimp Litopenaeus vannamei under normal condition and stress of acute low salinity. Fish and Shelfish Immunology 62: 195-201. https://doi.org/10.1016/j.fsi.2017.01.015

Zhu, X.Z., Liu, Y.J., Tian, L.X., Mai, K.S., Zheng, S.X., Pan, Q.J., Cai, M.C., Zheng, C.Q., Zhang, Q.H., and Hu, Y. 2010. Effects of dietary protein and lipid levels on growth and energy productive value of pacific white shrimp, Litopenaeus vannamei, at different salinities. Aquac. Nutr. 16, 392-399. https://doi.org/10.1111/j.1365-2095.2009.00677.x. 


\section{Table $\mathbf{1}$ (on next page)}

Table 1. Composition of control and experimental diets.

Data expressed in dry weight pecentage of diets

*Commercial mix from PIASA, SA de CV.

** Commercial yeast (Saccharomyces cerevisiae).

‡ Laboratory vitamins mix: Choline, Butylated hydroxytoluene (BHT), cholesterol,Vitamin A, C, B1, B2, B3, B5, B6, B7, B8, B9, B12, B20, D, E, and K.

† Laboratory minerals mix: $\mathrm{NaH}_{2} \mathrm{PO}_{4}, \mathrm{CaH}_{2} \mathrm{PO}_{4}, \mathrm{KH}_{2} \mathrm{PO}_{4}, \mathrm{MgSO}_{4} \cdot \mathrm{H}_{2} \mathrm{O}, \mathrm{ZnSO}_{4} \cdot 7 \mathrm{H}_{2} \mathrm{O}, \mathrm{ZnSO}_{4} \cdot \mathrm{H}_{2} \mathrm{O}, \mathrm{MnSO}_{4}$ $.4 \mathrm{H}_{2} \mathrm{O}, \mathrm{FeSO}_{4}, \mathrm{CuSO}_{4} .7 \mathrm{H}_{2} \mathrm{O}, \mathrm{Na}_{2} \mathrm{SeO}_{3}, \mathrm{KI}_{1} \mathrm{Na}_{2} \mathrm{MoO}_{4}$.

†† Laboratory strain mix of Wickerhamomyces anomalus, Pichia kudriavzevii, Lactobacillus plantarum and Bacillus subtilis.

㧊 Organic acids Mix: propionic, butilic acetic and nicotinic acids

t†† Laboratory free amino acids: arginine, methionine, lysine, tryptophan, and threonine. 
1

\begin{tabular}{|l|c|c|}
\hline \multicolumn{1}{|c|}{ Ingredient } & Control & Experimental \\
\hline Fish meal & 20 & 6 \\
\hline Soybean meal & 37.2 & 24.1 \\
\hline Wheat meal & 35 & 44.5 \\
\hline Fish oil & 4 & 2.6 \\
\hline Soy lecithin & 3 & 5 \\
\hline Alginate acid & 0.75 & 2 \\
\hline Vitamin Mix & $0.09^{*}$ & $0.27 \ddagger$ \\
\hline Mineral Mix & $0.05 *$ & $8.5 \dagger$ \\
\hline Yeast** & 0 & 4 \\
\hline Probiotic Mix $\dagger \dagger$ & 0 & 1.2 \\
\hline Organic acids Mix $+*$ & 0 & 0.5 \\
\hline Fish oil + Astaxanthin & 0 & 0.4 \\
\hline Free amino acids mix $+\dagger \dagger$ & 0 & 1 \\
\hline
\end{tabular}




\section{Table 2 (on next page)}

Proximate analysis of control and experimental diets

Data expressed as mean \pm standard error Values with different letters in the same row present significant differences $(\mathrm{P}<0.05)$. 
1

\begin{tabular}{|l|l|l|}
\hline & Control & Experimental \\
\hline Crude protein (\%) & $40.4 \pm 0.2^{\mathrm{a}}$ & $26.1 \pm 0.1^{\mathrm{b}}$ \\
\hline Lipid (\%) & $8.1 \pm 0.1^{\mathrm{a}}$ & $9.0 \pm 0.05^{\mathrm{b}}$ \\
\hline Nitrogen-free extract (\%) & $43.3^{\mathrm{a}}$ & $54.1^{\mathrm{b}}$ \\
\hline Water content (\%) & $6.4 \pm 0.1^{\mathrm{a}}$ & $4.7 \pm 0.1^{\mathrm{b}}$ \\
\hline Nitrogen (\%) & $6.5 \pm 0.02^{\mathrm{a}}$ & $4.2 \pm 0.02^{\mathrm{b}}$ \\
\hline Crude fiber (\%) & $1.0 \pm 0.1^{\mathrm{a}}$ & $0.6 \pm 0.1^{\mathrm{b}}$ \\
\hline Ashes (\%) & $7.2 \pm 0.04^{\mathrm{a}}$ & $10.2 \pm 0.02^{\mathrm{b}}$ \\
\hline Gross energy (cal/g) & $4809.6 \pm 3.1^{\mathrm{a}}$ & $4391.4 \pm 1.4^{\mathrm{b}}$ \\
\hline
\end{tabular}

2 


\section{Table 3(on next page)}

Fatty acids of control and experimental diets.

Data expressed as means \pm standard error Data expressed as means \pm standard error. $\Sigma$ SAT: Sum of saturated fatty acids, $\Sigma$ MUFA: Sum of monounsaturated fatty acids, $\Sigma$ PUFA: Sum of polyunsaturated fatty acids, $\Sigma$ HUFA: Sum of highly unsaturated fatty acids, $\Sigma$ n-6: Sum of $n-6, \Sigma$ $n-3$ : Sum of $n-3$. Values with different letters in the same row present significant differences $(P<0.05)$ 


\begin{tabular}{lcc} 
Fatty acid (\%) & Control & Experimental \\
\hline $\mathbf{1 6 : 0}$ & $15.54 \pm 0.08^{\mathrm{a}}$ & $14.40 \pm 0.09^{\mathrm{b}}$ \\
$\mathbf{1 8 : 0}$ & $4.20 \pm 0.03^{\mathrm{a}}$ & $3.92 \pm 0.02^{\mathrm{b}}$ \\
$\mathbf{1 6 : 1 n - 7}$ & $3.96 \pm 0.01^{\mathrm{a}}$ & $3.51 \pm 0.02^{\mathrm{b}}$ \\
$\mathbf{1 8 : 1 n - 9}$ & $13.44 \pm 0.04^{\mathrm{a}}$ & $14.64 \pm 0.02^{\mathrm{b}}$ \\
$\mathbf{1 8 : 1 n - 7}$ & $2.57 \pm 0.02^{\mathrm{a}}$ & $2.23 \pm 0.01^{\mathrm{b}}$ \\
$\mathbf{2 0 : 1 n - 9}$ & $1.64 \pm 0.01^{\mathrm{a}}$ & $1.53 \pm 0.003^{\mathrm{b}}$ \\
$\mathbf{2 2 : 1 n - 1 1}$ & $2.30 \pm 0.04^{\mathrm{a}}$ & $2.17 \pm 0.03^{\mathrm{a}}$ \\
$\mathbf{1 8 : 2 n - 6}$ & $27.69 \pm 0.03^{\mathrm{a}}$ & $31.44 \pm 0.14^{\mathrm{b}}$ \\
$\mathbf{1 8 : 3 n - 3}$ & $3.84 \pm 0.02^{\mathrm{a}}$ & $4.32 \pm 0.01^{\mathrm{b}}$ \\
$\mathbf{1 8 : 4 n - 3}$ & $1.09 \pm 0.01^{\mathrm{a}}$ & $1.00 \pm 0.01^{\mathrm{b}}$ \\
$\mathbf{2 0 : 4 n - 6}$ & $0.43 \pm 0.001^{\mathrm{a}}$ & $0.36 \pm 0.01^{\mathrm{b}}$ \\
$\mathbf{2 0 : 5 n - 3}($ EPA) & $6.81 \pm 0.06^{\mathrm{a}}$ & $6.15 \pm 0.06^{\mathrm{b}}$ \\
$\mathbf{2 2 : 5 n - 6}$ & $1.28 \pm 0.01^{\mathrm{a}}$ & $1.16 \pm 0.02^{\mathrm{b}}$ \\
$\mathbf{2 2 : 6 n - 3}(\mathbf{D H A})$ & $8.27 \pm 0.10^{\mathrm{a}}$ & $7.33 \pm 0.18^{\mathrm{b}}$ \\
$\boldsymbol{\Sigma}$ SAT & $23.96 \pm 0.11^{\mathrm{a}}$ & $21.74 \pm 0.13^{\mathrm{b}}$ \\
$\boldsymbol{\Sigma}$ MUFA & $25.86 \pm 0.12^{\mathrm{a}}$ & $25.75 \pm 0.01^{\mathrm{a}}$ \\
$\Sigma$ PUFA & $50.19 \pm 0.23^{\mathrm{a}}$ & $52.50 \pm 0.13^{\mathrm{b}}$ \\
$\Sigma$ HUFA & $18.32 \pm 0.18^{\mathrm{a}}$ & $16.41 \pm 0.28^{\mathrm{b}}$ \\
Fatty acids total $(\mathbf{m g} / \mathbf{g})$ & $8.13 \pm 0.31^{\mathrm{a}}$ & $8.75 \pm 0.38^{\mathrm{a}}$ \\
\hline
\end{tabular}




\section{Table 4(on next page)}

Biological performance (mean \pm standard error) of juveniles of $L$. vannamei reared at37 and 6 psu, fed with control and experimental diets for 6 weeks

Results of two-way ANOVA are indicated in last columns (NS= Not significant). Following Tukey HSD test, values with different letters in the same row present significant differences $(P<0.05)$.

$W G=$ Weight gain; $S G R=$ Specific growth rate; $F C R=$ Feed conversion rate; $\mathrm{PER}=$ protein efficiency ratio 
1

\begin{tabular}{|l|l|l|l|l|l|l|l|}
\hline Salinity & \multicolumn{3}{|l|}{$\mathbf{3 7}$ psu } & 6 psu & ANOVA & \\
\hline Diet & Control & Experimental & Control & Experimental & Salinity & Diet & SxD \\
\hline WG (\%) & $304 \pm 8^{\mathrm{a}}$ & $246 \pm 6^{\mathrm{b}}$ & $253 \pm 7^{\mathrm{b}}$ & $274 \pm 5^{\mathrm{b}}$ & NS & $<\mathbf{0 . 0 5}$ & $<0.01$ \\
\hline SGR (\%/day) & $2.5 \pm 0.1^{\mathrm{a}}$ & $2.2 \pm 0.05^{\mathrm{b}}$ & $2.2 \pm 0.1^{\mathrm{b}}$ & $2.4 \pm 0.04^{\mathrm{ab}}$ & NS & NS & $<0.01$ \\
\hline FCR & $1.9 \pm 0.1^{\mathrm{b}}$ & $2.1 \pm 0.1^{\mathrm{ab}}$ & $2.5 \pm 0.2^{\mathrm{a}}$ & $2.1 \pm 0.1^{\mathrm{ab}}$ & NS & NS & $<0.05$ \\
\hline Survival (\%) & $91.8 \pm 5.8^{\mathrm{ab}}$ & $93.7 \pm 3.9^{\mathrm{ab}}$ & $72.1 \pm 6.5^{\mathrm{b}}$ & $98.1 \pm 1.9^{\mathrm{a}}$ & NS & $<0.05$ & $<0.05$ \\
\hline PER & $1.4 \pm 0.1^{\mathrm{b}}$ & $1.9 \pm 0.04^{\mathrm{a}}$ & $1.1 \pm 0.01^{\mathrm{c}}$ & $1.9 \pm 0.01^{\mathrm{a}}$ & NS & $<\mathbf{0 . 0 1}$ & $<0.05$ \\
\hline $\begin{array}{l}\text { Productive } \\
\text { performance }\end{array}$ & $1.23 \pm 0.15^{\mathrm{a}}$ & $1.0 \pm 0.10^{\mathrm{ab}}$ & $0.7 \pm 0.12^{\mathrm{b}}$ & $1.1 \pm 0.05^{\mathrm{a}}$ & NS & NS & $<0.01$ \\
\hline
\end{tabular}

2 


\section{Table 5 (on next page)}

Biochemical levels (means \pm standard error) in hemolymph of $L$. vannamei reared at 37 and 6 psu(salinity(S)), fed with control and experimental (Exp) diets (D) for 6 weeksand exposed to hypoxia and escape response (st= stress test).

Results of three-way ANOVA are indicated in last columns $(*=\mathrm{P}<0.05, * *=\mathrm{P}<0.01, \mathrm{NS}=$ Not significant). Only when significant triple interaction was significant, values with different letters in the same row present significant differences $(P<0.05)$, following Tukey HSD test. 


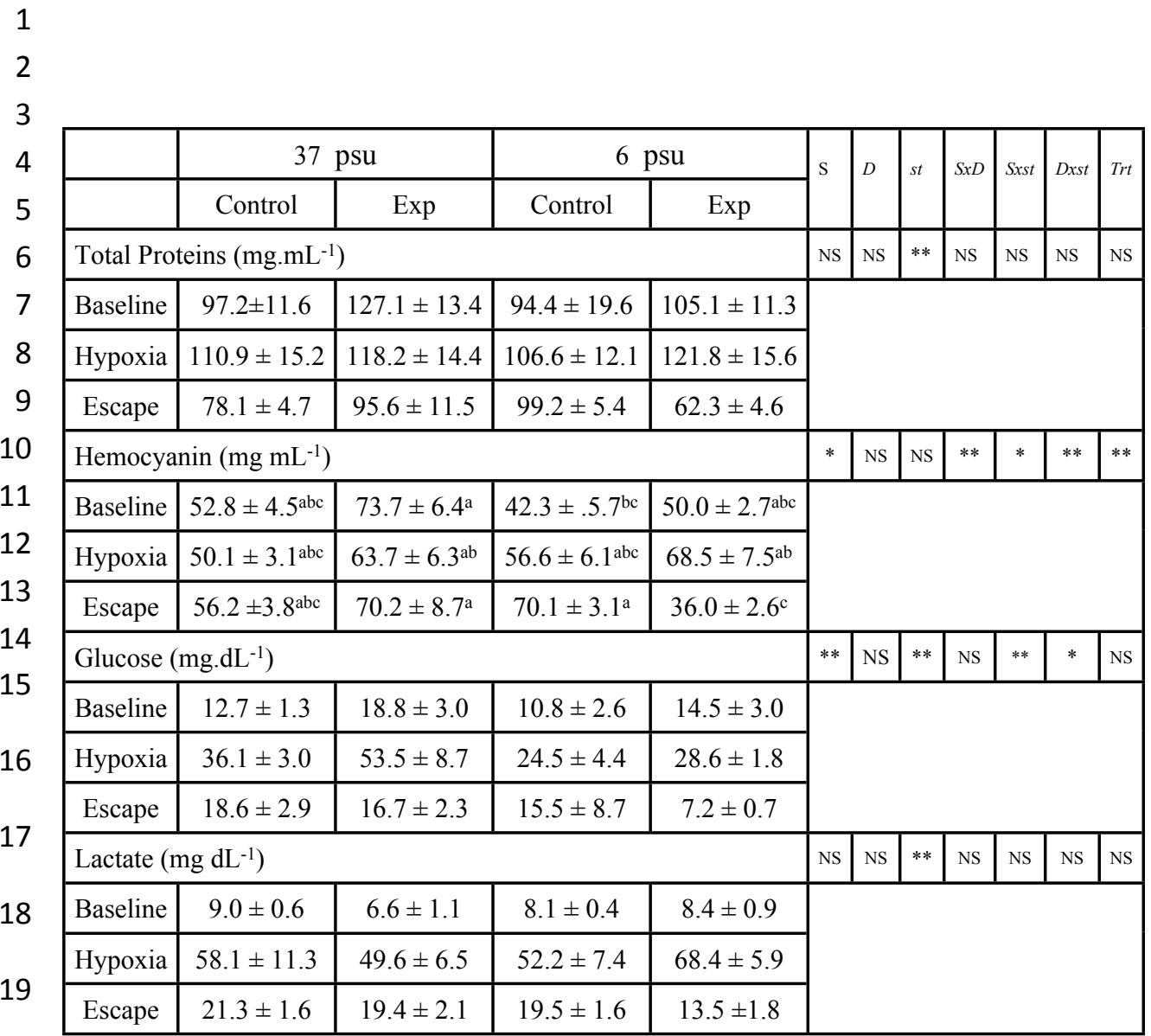




\section{Table 6(on next page)}

Biochemical levels (means \pm standard error) in tissues of $L$. vannamei reared at 37 and 6 psu (salinity (S)), fed with controland experimental (Exp) diets (D) for 6 weeks and exposed to hypoxia and escaperesponse (st= stress test).

Results of three-way ANOVA are indicated in last columns $(*=\mathrm{P}<0.05, * *=\mathrm{P}<0.01$, NS $=$ Not significant). Only when significant triple interaction was significant, values with different letters in the same row present significant differences $(P<0.05)$, following Tukey HSD test. 
1

\begin{tabular}{|c|c|c|c|c|c|c|c|c|c|c|c|c|}
\hline & & \multicolumn{2}{|c|}{$37 p s u$} & \multicolumn{2}{|c|}{$6 p s u$} & \multirow[t]{2}{*}{$\mathrm{S}$} & \multirow[t]{2}{*}{$D$} & \multirow[t]{2}{*}{$s t$} & \multirow[t]{2}{*}{$S x D$} & \multirow[t]{2}{*}{ Sxst } & \multirow[t]{2}{*}{ Dxst } & \multirow[t]{2}{*}{$\operatorname{Trt}$} \\
\hline & & Control & $\operatorname{Exp}$ & Control & $\operatorname{Exp}$ & & & & & & & \\
\hline \multirow{12}{*}{ 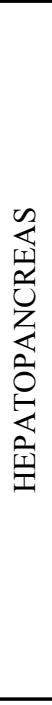 } & \multicolumn{5}{|c|}{ Total proteins (mg.g $\left.{ }^{-1}\right)$} & NS & NS & NS & $*$ & $* *$ & NS & NS \\
\hline & Baseline & $283 \pm 18$ & $267 \pm 22$ & $362 \pm 43$ & $258 \pm 33$ & & & & & & & \\
\hline & Hypoxia & $337 \pm 27$ & $351 \pm 42$ & $258 \pm 29$ & $246 \pm 17$ & & & & & & & \\
\hline & Escape & $225 \pm 10$ & $285 \pm 19$ & $369 \pm 28$ & $294 \pm 30$ & & & & & & & \\
\hline & \multicolumn{5}{|c|}{ Total lipids (mg.g $\mathrm{g}^{-1}$ ) } & $* *$ & NS & NS & $* *$ & NS & NS & $*$ \\
\hline & Baseline & $206 \pm 22^{a b c}$ & $184 \pm 24 \mathrm{abc}$ & $206 \pm 50^{\mathrm{abc}}$ & $169 \pm 27 \mathrm{abc}$ & & & & & & & \\
\hline & Hypoxia & $257 \pm 17^{\mathrm{c}}$ & $183 \pm 13^{a b c}$ & $126 \pm 18$ ab & $179 \pm 13^{a b c}$ & & & & & & & \\
\hline & Escape & $234 \pm 10 \mathrm{bc}$ & $165 \pm 14^{\mathrm{abc}}$ & $119 \pm 34^{\mathrm{a}}$ & $191 \pm 30^{a b c}$ & & & & & & & \\
\hline & \multicolumn{5}{|c|}{ Triglycerides (mg.g ${ }^{-1}$ ) } & $* *$ & $* *$ & NS & $* *$ & NS & NS & NS \\
\hline & Baseline & $56 \pm 5$ & $53 \pm 7$ & $27 \pm 6$ & $49 \pm 7$ & & & & & & & \\
\hline & Hypoxia & $53 \pm 3$ & $68 \pm 3$ & $29 \pm 7$ & $61 \pm 3$ & & & & & & & \\
\hline & Escape & $55 \pm 3$ & $60 \pm 4$ & $30 \pm 10$ & $61 \pm 7$ & & & & & & & \\
\hline \multirow{12}{*}{ 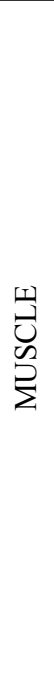 } & \multicolumn{5}{|c|}{ Total proteins (mg.g $\left.{ }^{-1}\right)$} & NS & NS & $* *$ & NS & NS & NS & NS \\
\hline & Baseline & $504 \pm 57$ & $560 \pm 32$ & $548 \pm 37$ & $584 \pm 25$ & & & & & & & \\
\hline & Hypoxia & $643 \pm 27$ & $656 \pm 22$ & $593 \pm 27$ & $608 \pm 10$ & & & & & & & \\
\hline & Escape & $693 \pm 20$ & $727 \pm 16$ & $694 \pm 69$ & $705 \pm 47$ & & & & & & & \\
\hline & \multicolumn{5}{|c|}{ Lactate $\left(\mathrm{mg} \cdot \mathrm{g}^{-1}\right)$} & $* *$ & $* *$ & $* *$ & $*$ & NS & NS & NS \\
\hline & Baseline & $5.9 \pm 0.4$ & $6.2 \pm 0.8$ & $3.8 \pm 0.4$ & $5.7 \pm 0.4$ & & & & & & & \\
\hline & Hypoxia & $6.6 \pm 0.6$ & $7.8 \pm 0.4$ & $4.1 \pm 0.7$ & $5.3 \pm 0.5$ & & & & & & & \\
\hline & Escape & $7.8 \pm 0.4$ & $8.5 \pm 0.5$ & $5.4 \pm 0.6$ & $8.2 \pm 0.7$ & & & & & & & \\
\hline & \multicolumn{5}{|c|}{ Total lipids (mg.g $\left.\mathrm{g}^{-1}\right)$} & NS & $* *$ & $* *$ & NS & NS & NS & NS \\
\hline & Baseline & $26.2 \pm 5.2$ & $42.0 \pm 4.9$ & $26.4 \pm 2.7$ & $35.9 \pm 4.0$ & & & & & & & \\
\hline & Hypoxia & $37.9 \pm 1.8$ & $29.1 \pm 4.9$ & $36.4 \pm 3.2$ & $43.9 \pm 4.4$ & & & & & & & \\
\hline & Escape & $43.5 \pm 6.0$ & $49.1 \pm 2.3$ & $45.3 \pm 4.0$ & $57.6 \pm 6.3$ & & & & & & & \\
\hline
\end{tabular}

2

3

4

5

6 


\section{Table 7 (on next page)}

Concentration ofArg-P, nucleotides and Adenylate energy charge (AEC) (means \pm standard error)in muscle of $L$. vannamei reared at 37 and 6 psu (salinity (S)), fed with control and experimental (Exp) diets (D) for6 weeks and exposed to hypoxia and escap

Results of three-way ANOVA are indicated in last columns ( $*=\mathrm{P}<0.05, * *=\mathrm{P}<0.01, \mathrm{NS}=$ Not significant). Only when significant triple interaction was significant, values with different letters in the same row present significant differences $(P<0.05)$, following Tukey HSD test.

TAN: Total adenylic nucleotides; AEC: adenylic energy charge 
1

\begin{tabular}{|c|c|c|c|c|c|c|c|c|c|c|c|}
\hline & \multicolumn{2}{|c|}{$37 p s u$} & \multicolumn{2}{|c|}{$6 p s u$} & \multirow{2}{*}{ S } & \multirow{2}{*}{$D$} & \multirow{2}{*}{ st } & \multirow{2}{*}{$S x D$} & \multirow{2}{*}{ Sxst } & \multirow{2}{*}{ Dxst } & \multirow{2}{*}{$\operatorname{Tr} t$} \\
\hline & Control & $\operatorname{Exp}$ & Control & $\operatorname{Exp}$ & & & & & & & \\
\hline \multicolumn{5}{|c|}{ Arg-P $\left(\mu\right.$ moles.g $\left.{ }^{-1}\right)$} & NS & $* *$ & $* *$ & NS & NS & * & $*$ \\
\hline Baseline & $2.51 \pm 1.04 \mathrm{abc}$ & $5.93 \pm 1.37 \mathrm{bcd}$ & $2.97 \pm 0.68 \mathrm{abc}$ & $6.63 \pm 1.20^{\mathrm{cd}}$ & & & & & & & \\
\hline Hypoxia & $1.22 \pm 0.43^{\mathrm{a}}$ & $8.24 \pm 1.64^{\mathrm{d}}$ & $1.51 \pm 0.40^{\mathrm{a}}$ & $3.05 \pm 0.68 \mathrm{abc}$ & & & & & & & \\
\hline Escape & $1.02 \pm 0.24^{\mathrm{a}}$ & $2.14 \pm 0.48^{\mathrm{ab}}$ & $0.62 \pm 0.19^{\mathrm{a}}$ & $2.08 \pm 0.32^{\mathrm{ab}}$ & & & & & & & \\
\hline \multicolumn{5}{|c|}{ AMP $\left(\mu\right.$ moles. $\left.\mathrm{g}^{-1}\right)$} & $* *$ & $* *$ & NS & $*$ & NS & NS & NS \\
\hline Baseline & $1.0 \pm 0.16$ & $0.38 \pm 0.04$ & $1.34 \pm 0.19$ & $0.48 \pm 0.10$ & & & & & & & \\
\hline Hypoxia & $1.11 \pm 0.16$ & $0.34 \pm 0.06$ & $1.32 \pm 0.24$ & $0.51 \pm 0.14$ & & & & & & & \\
\hline Escape & $0.71 \pm 0.10$ & $0.60 \pm 0.19$ & $1.54 \pm 0.27$ & $0.55 \pm 0.12$ & & & & & & & \\
\hline \multicolumn{5}{|c|}{ ADP $\left(\mu\right.$ moles.g $\left.g^{-1}\right)$} & $* *$ & $* *$ & NS & NS & NS & NS & NS \\
\hline Baseline & $2.97 \pm 0.30$ & $2.26 \pm 0.13$ & $3.51 \pm 0.26$ & $2.48 \pm 0.21$ & & & & & & & \\
\hline Hypoxia & $3.47 \pm 0.22$ & $2.07 \pm 0.19$ & $3.44 \pm 0.24$ & $3.01 \pm 0.29$ & & & & & & & \\
\hline Escape & $3.22 \pm 0.18$ & $2.72 \pm 0.26$ & $3.42 \pm 0.43$ & $3.33 \pm 0.21$ & & & & & & & \\
\hline \multicolumn{5}{|c|}{ ATP $\left(\mu\right.$ moles. $\left.\mathrm{g}^{-1}\right)$} & NS & $* *$ & NS & NS & NS & NS & NS \\
\hline Baseline & $4.61 \pm 0.32$ & $7.07 \pm 0.30$ & $5.03 \pm 0.26$ & $7.54 \pm 0.70$ & & & & & & & \\
\hline Hypoxia & $5.19 \pm 0.41$ & $6.58 \pm 0.52$ & $5.69 \pm 0.61$ & $7.63 \pm 0.60$ & & & & & & & \\
\hline Escape & $5.52 \pm 0.37$ & $6.21 \pm 0.44$ & $4.67 \pm 0.60$ & $7.78 \pm 0.40$ & & & & & & & \\
\hline \multicolumn{5}{|c|}{ TAN $\left(\mu\right.$ moles. $\left.\mathrm{g}^{-1}\right)$} & $* *$ & $*$ & NS & $*$ & NS & NS & NS \\
\hline Baseline & $8.6 \pm 0.5$ & $9.7 \pm$ & $9.9 \pm 0.4$ & $10.5 \pm 0.7$ & & & & & & & \\
\hline Hypoxia & $9.8 \pm 0.4$ & $9.0 \pm 0.6$ & $10.4 \pm 0.4$ & $11.1 \pm 0.5$ & & & & & & & \\
\hline Escape & $9.5 \pm 0.3$ & $9.5 \pm 0.2$ & $9.6 \pm 0.4$ & $11.7 \pm 0.3$ & & & & & & & \\
\hline \multicolumn{5}{|c|}{$\mathrm{AEC}(\mathrm{ATP}+1 / 2 \mathrm{ADP} / \mathrm{ATP}+\mathrm{ADP}+\mathrm{AMP})$} & NS & $* *$ & NS & NS & NS & NS & NS \\
\hline Baseline & $0.71 \pm 0.03$ & $0.84 \pm 0.01$ & $0.69 \pm 0.02$ & $0.83 \pm 0.02$ & & & & & & & \\
\hline Hypoxia & $0.71 \pm 0.03$ & $0.85 \pm 0.02$ & $0.70 \pm 0.03$ & $0.82 \pm 0.03$ & & & & & & & \\
\hline Escape & $0.75 \pm 0.02$ & $0.79 \pm 0.03$ & $0.66 \pm 0.04$ & $0.81 \pm 0.02$ & & & & & & & \\
\hline
\end{tabular}


